\title{
Situational Analysis of Teacher Capacity Building Paradigm in Khyber Pakhtunkhwa - Pakistan
}

\author{
Mazhar Islam ${ }^{1, *}$, Prof. Dr. Mussawar Shah ${ }^{1}$, Dr. Saima Sarir ${ }^{1}$ and Prof. Dr. Abbas Ullah Jan ${ }^{2}$ \\ 'Department of Rural Sociology, University of Agriculture, Peshawar, Pakistan; \\ mazharislamkhattak@gmail.com \\ drsaimasarrir@aup.edu.pk \\ 2Department of Agriculture \& Applied Economics The University of Agriculture, Peshawar, Pakistan; \\ abbasjan@aup.edu.pk.
}

\begin{abstract}
Objectives: To assess the teacher capacity building paradigm on situational grounds under the purview of 2013 policy reforms. Methods: The present study was conducted in three districts Kohat, Karak, and Hungu of Khyber Pakhtunkhwa Pakistan in light of 2013 education reforms. A total size of 540 primary school teachers were randomly interviewed from the fore mentioned areas through multistage sampling procedure in order to assess the situational analysis of teacher capacity building in light of the policy paradigm. Findings: While taking age, educational qualification, and teaching experience as control variables, the age was found significantly $(P<0.000)$ affecting teacher attitude towards improvement in primary education, qualified and experienced teachers had a significant $(P<0.000)$ impact on students achievement. At bi-variate level, the findings indicated that consistent training had led to capacity enhancement of teachers, but some of the teachers were laggards to participate in trainings, led the position with incompetence to survive in the newly formulated reforms regime as shown a significant association $(P<0.000)$ with improvement in primary education. Novelty/improvements: The study further divulged that teachers with young age and at the twilight of professional life had taken maximum benefits by reforming themselves; teachers with higher qualification had more inclination to enhance their capacity in comparison to teachers with low level of education.
\end{abstract}

Keywords: Primary Education, Policy Reforms, Teacher Capacity Building, Educational Reforms, Teacher Training.

\section{Introduction}

Education has always been a major concern in human society. It enhances the person's knowledge, perceptions and mental strengthens along with playing an important role in creating and developing individual behaviour. Moreover, it is essential for sustainable development, peace, and stability within and between the countries. The understanding and enlightenment one receives from education improves his/her intellect, knowledge, and skills. 1

Basically, it plays a central role in capacity building to promote economic growth and human development in the society. Provision of education is one of the primary responsibilities of the state. Literacy rate in Pakistan has been growing at a snail's pace. Pakistan is among those countries where literacy rate is very low. Especially, female literacy rate is $45 \%$ against male $69 \%$ literacy rate. The

${ }^{*}$ Author for correspondence 
province-wise break-up indicates that Punjab has the top literacy ratio of $61 \%$, with 71 and 55pc of girls and boys, respectively. In Sindh, the ratio remained $60 \mathrm{pc}$ with $71 \mathrm{pc}$ boys and 55pc girls, respectively. Khyber Pakhtunkhwa is at $53 \%$ and the gender-based ratio is 71 and 35 percent for boys and girls, respectively. Baluchistan came out in the last with a literacy rate of 44 percent with 61 percent boys as compared to 25 percent girls. Primary education occupies a fundamental place in the entire education system. Educationists call it backbone or cornerstone of the entire education system, while sociologists consider it a valuable social reform tool as it directly relates to the information and initiative stage of learning in the society. However, it has been neglected in the past despite its conspicuous role for the development of societies across the globe. The sole purpose of its primary attention is linked to its continuous supply of trained workforce, which embodies the sustainability of social system. $\underline{2}-\underline{5}$

The 2013 elections compiled with a dynamic ship towards constitutional amendment in the shape of 18th amendment also supported the initiatives of improvement in this vital field of human capital improvement through provision of adequate facilities both in infrastructure and trained human capital in light of 2015 millennium development goal. This development goal entails free access to primary education albeit gender consideration and minority with the revision of curriculum. KP, one of the provinces while foreseeing into this vital field of human life, took a leading step forward by framing new vibrant polices for the sole purpose of uplift in quality education and enhancement in enrolment along with provision and improvement in the existing infrastructure services, revised curricula and enhancement in budget, to be adjusted through a strong monitoring \& evaluation system. Taking a leading role to increase enrolment by sharing more commitment on account of quality education. Initiation of enrolment campaigns, student's assessment mechanisms, evaluation of teachers' capacities, rationalization of teaching staff, and provision of missing equipment in public schools are some of the essential measures introduced to improve the educational environment. In addition, more emphasis was laid on services on revision of syllabus up to 5th class and uniform exam system for dichotomous schooling system i.e. public \& private.

Teacher capacity building is one of the integral components of education. Teacher competencies are to be improved to meet the new responsibilities and challenges.
It is the education which enables people to address the social, moral, political, and economic problems they are faced with.

In order to make the students competitive enough to deal with such problems, we need to build the capacity of the teachers with particular reference to the new roles and responsibilities for coping the new challenges upfront. Teachers training should address how to disseminate the knowledge systematically and in a more efficient way, keeping in view the cultural and moral values of the society. Specialization in the subject matter and pedagogy can supplement such process. - For, the teacher training is not an activity aimed at growing new knowledge, but also the skills and aptitude needed for the development and character building. Reported that quality improvement related discussions on education are directly related to teacher's capacity program relevance, assessment systems, teaching methods, pedagogical environment, and materials. One of the main criticisms of teacher's capacity, especially in the public sector, relates to no improvement in the learning outcomes of students in proportion to the amount spent on training. In Ref., 7 Shami and Hussain stated that solid academic background in relation to general education is a major factor in determining the professional and academic quality of a teacher. The learning of teaching methods and techniques in education and specialized areas further enhance this process. It is again the education which a teacher receives in school and colleges, enhances his/her prestige and competence. It is further supplemented by the teacher's commitment and attention they give to students. Further reported that in order to enter into the teaching profession one should have to sufficiently train the teacher to perform his/her function appropriately. This is particularly needed in the professions such as law, medicine, and architecture which could be further strengthened by availing trainings.

Cognitive and effective abilities of a person are developed through education, whereas effective training depends on theoretical knowledge, teaching skills and ability being acquired through training programme. During this process, relevant knowledge on a specific topic is obtained to pass on to the students. Actually, the development of a country is determined by the role played by a teacher which mainly depends on the education and professional training of the teachers. They have to equip themselves with the knowledge and skills to attain the practices, policies, and procedures demanded by the new trends in 21 st century as one of its essentials. $\frac{8}{-}$ 
In Ref.,, Hiebert et al. explored the importance of teacher and teacher education as a major factor with respect to quality of education. They called student learning as the major goal of the teacher. To achieve this, UNESCO has initiated a number of incentives for the improvement of quality education at different levels. The major emphasis was on pre-service and in-service trainings. The UNESCO further mobilized the member states around the world to develop and implement viable polices to meet the international standard needed for achieving the quality education. For that assistance was given to build teachers' capacity to enhance their professional skills not only in their respective countries, but also it the member countries are Table 1.

Implementation of the program for capacity building of the teacher by the different donors in Pakistan has been implemented in all the provinces including Azad Jammu Kashmir and Northern Areas of Pakistan through the collaboration of educational department. NGOs and other institutions at private sector mainly focused on in-service professional development of female teachers belonging to the rural areas of Pakistan. During this process, teacher's capacity was enhanced through innovation based on new talent and traditions in vogue in developed countries. However, little has been achieved in this regard and the long-term impact of the sustainability of the new trends and methodology is still awaited. This is mainly due to lack of the relevant study for making polices in connection with achieving the quality education through quality teachers. Moreover, teachers' capacity building has been the other major focus in the government policies since the independence of the country in 1947. It was basically the federal government responsibility till 18th amendment in the constitution on April 8, 2010. However, each province has separate centralized organizational structure to enhance capacity of the teachers at primary, middle, and secondary level. Currently, there are more than 300

Table 1. A comparative sketch of Pakistan with neighbouring status comparative statistics of the region

\begin{tabular}{|l|l|l|l|}
\hline S. no & Country & Enrolment & Drop out \\
\hline 1 & India & $94 \%$ & $6.4 \%$ \\
\hline 2 & Pakistan & $70 \%$ & $30.3 \%$ \\
\hline 3 & Sri Lanka & $98 \%$ & $1.9 \%$ \\
\hline 4 & Bangladish & $84 \%$ & $16.2 \%$ \\
\hline 5 & Malaysia & $97 \%$ & $7.8 \%$ \\
\hline
\end{tabular}

Source: Nation Master (nationmaster.com). teacher training institutes offering a number of Initial Teacher Education (ITE) programs in Pakistan in the public and private sectors. ${ }^{10}$ Globally, teacher's capacity is considered as a corner stone in educational development. In fact, a solid and effective educational system of a country cannot be built without building capacity of the teachers and following a continuous assessment of teaching activities at schools. The incumbent government policies and programs must have to provide the necessary measures and resources needed to build teachers capacities according to the needs of the 21 st century.In Ref., 11 the authors also reported that the teacher role has important components of education at global level. The term education is a dynamic, social phenomenon which changes continuously with the passage of time. In order to make it up to date and sustainable a number of innovative changes were made through diversifying the curriculum and making appropriate changes in teaching practices. The major aim of such invention was meeting the educational system on the basis of needs of the 21st century where globalization has integrated the society to a large extent. It is called it a very important investment for the improvement of quality education. A qualitative change in education is the need of the day not only for enhancing the teachers' capability but also to play a positive role in the development of a country. There is a positive relationship between quality teaching and teachers qualification, but for the skill, proper attitude, practice and evaluation through capacity building is required to enhance the process. Initial training plays an important role in the professional development of teachers. A new approach based on a vigilant and participative representation of the teacher for a sustainable development of education to meet the knowledge, skills, and competency is essential. This makes mandatory for the teacher to build their capacity and ability to meet such changes for ensuring a most appropriate role and function at school.

This innovation and sophisticated information system and communication technology yet another key to enhance the teacher capacity. $\underline{12}$ Further believed that it is the training which empowers trainees' efficiency over the subjects and pedagogy. Awareness about students' standard and responsibility of grooming young generation further accelerates the process.

The development of educator capacity and commitment is not limited to isolated or periodic professional development events or programs. Rather, it is important to conceptualize full professional development 
reform as a career process in the incumbent systems and policies allowing educators (teachers, administrators, and supervisors) to acquire, expand, deepen, and refresh their knowledge, skills, and commitment to accomplish their work more effectively. $\frac{13}{\text { It }}$ also indicated towards a positive relationship between the qualities of education with effective training. There is a need to invest in teacher education to get the multiple effects of education not only in terms of effects on students but the whole society. The learning outcome influence many people in many ways; however, it is also not necessary that every student will get the same benefits from the teacher knowledge, competence and know-how. Similarly, one cannot expect that good teaching automatically generates rather conducive environment is the important pillar in this regard. Despite this, it is generally agreed that a positive relationship between bad teaching and bad learning is in prevalence. As a whole the teacher education and training is the aimed solution of solving such problem. Has further reported that teacher education is the base of the education system throughout the world, however, little attention is given in this regard. Lack of political well is the main factor behind the process. This is supplemented by allocation of inefficient resources, poor governance, and dysfunctional management. It was further supported by authors, $\underline{14}$ who reported that lack of sustainable change in teacher capacity and conductive learning culture in schools has been worked over since independence of Pakistan. Moreover, most of changes were proved bubbles and disappeared with the termination of funding by the donor agencies. Keeping into consideration the fore mentioned facts, the present study is designed to proceed with the sole objectives of exploring the situational analysis of teacher capacity building paradigm in $\mathrm{KP}$ under the purview of 2013 educational policy reforms.

\section{Research Methodology}

The study conducted in 2018 was based on primary data collected from three Districts namely Kohat, Karak, and Hungu. According to the Independent Monitoring Unit (IMU) Elementary \& Secondary Education Department Government of KPK, there are 439 primary schools and 1817 teachers in the three selected Districts namely Kohat, Karak, \& Hungu. A sample size of 540 devised were randomly collected using multi-stage sampling procedure. For further clarification see Table 2.
Table 2. Sampling and sample size distribution on the basis of number of schools

\begin{tabular}{|l|l|l|l|l|l|}
\hline $\begin{array}{l}\text { S. } \\
\text { no }\end{array}$ & $\begin{array}{l}\text { Number of } \\
\text { schools chosen } \\
\text { for the study area }\end{array}$ & Kohat & Karak & Hangu & Total \\
\hline 1. & Total schools & 231 & 119 & 89 & 439 \\
\hline a. & Sampled schools & 119 & 61 & 46 & 226 \\
\hline
\end{tabular}

Source: KPK Independent Monitoring Unit (IMU, 2018).

\subsection{Data Collection}

The study was based on both the primary and secondary data where the secondary data were collected from all the possible secondary sources, while for primary data a comprehensive interview schedule was designed in the light of study objectives and conceptual framework. It consists of a dependent and one independent variable. To check the inconsistency and make it relevant to the study objectives and conceptual framework, the questionnaire was pretested and necessary changes were made in the light of the pilot survey. Questionnaire was distributed to the respondents and the data were collected from the teachers working in the selected primary schools at the time of survey. Primary school was the basic unit or element of the study. Data were collected from those primary schools which were functional at the time of survey.

\subsection{Methods of Data Analysis}

After the collection of data, it was coded, edited, and then entered into the computer by using SPSS 21st version. The analysis of the data was made at uni-, bi-, and multi-variate levels. The univariate analysis comprised of frequency distribution and percentages of the sampled respondents. Bivariate analysis was carried out to measure the association between dependent and independents variables, while multi-variate results are based on the exploring the true \& untrue relationships between a dependent variable through control variables like age, educational qualification, \& teaching experience. Chi-square and Fisher Exact tests were used to measure the association. The Chi-squared test statistics for the test of independence summarizes how close the expected frequencies fall to the observed frequencies. It is represented by the symbol. Karl Pearson introduced 
the statistics in 1900 and used $\chi^{2}$ in sociological studies to test the degree of independence. $\frac{15}{5}$ The formula used to compute Chi-square is given in the following:

$$
\chi^{2}=\sum_{i=1}^{r} \sum_{j=1}^{r} \frac{\left(O_{\mathrm{ij}}-E_{\mathrm{ij}}\right)^{2}}{E_{\mathrm{ij}}}
$$

Where is chi-square, oij is observed frequencies in with row and $j$ th column. Eij is expected frequencies in I throw and $j$ th column whereas $r$ is number or rows and $n$ is number of column. The large summation sign, $\Sigma$ (capital sigma), tells us to compute the fractions for each cell and then sum over all cells to get. Fisher exact test was used when the frequencies in Table 3 was less than 5. Following was the formula of the test.

$$
\text { FisherExactTest }=\frac{(a+b) !(c+d) !(a+c) !(b+d) !}{N ! a ! b ! c ! d !}
$$

where $a, b, c$, and $d$ were the observed numbers in contingency (Table 4 ) while " $n$ " were the total number of observations.

\section{Results \& Discussion}

This chapter explains in detail the findings of the data after through application of different statistical tools. Univariate explains the profile of the sampled respondents in frequency distribution; bi-variate describes \& explains the relationship between dependent \& independent variable, through ascertaining the level of association upon application of $\chi^{2}$-test- statistics. While multivariate results are based on the exploring the true \&

Table 3. Table showing the respondents on the basis of demographic profile

\begin{tabular}{|l|l|l|l|l|l|}
\hline S. no. & $\begin{array}{l}\text { Number of } \\
\text { teachers selected } \\
\text { from the } \\
\text { population }\end{array}$ & Kohat & Karak & Hangu & Total \\
\hline 1. & $\begin{array}{l}\text { Total population } \\
\text { (teachers) }\end{array}$ & 1033 & 428 & 356 & 1817 \\
\hline a. & $\begin{array}{l}\text { Sampled } \\
\text { population }\end{array}$ & 307 & 127 & 106 & 540 \\
\hline
\end{tabular}

Source: KPK Independent Monitoring Unit (IMU, 2018).

Note: All those teachers who had working age group i.e. 25 to 60 years, constituted the universe of the study. It is essential to mention that 60 years are the retirement age in Pakistan.
Table 4. Conceptual framework. The following were the dependent and independent variable of the study.

\begin{tabular}{|l|l|}
\hline Independent variables & Dependent variables \\
\hline Teacher capacity building & $\begin{array}{l}\text { Improvement in primary } \\
\text { education }\end{array}$ \\
\hline
\end{tabular}

untrue relationships between dependent variable through control variables like age, educational qualification, \& teaching experience.

\subsection{Uni-Variate Analysis}

\subsubsection{Teacher's Capacity Building}

Teacher's capacity building occasioned by other inputs for a policy or structural component of a society could be invariable in strength and smooth deliverance. Education as an institution does imply the transmission of moral, political cum legal explanations, which could cover the other implicit features of human life as well. A teacher's capacity in terms of competitive environments under the preamble of the fore mentioned virtues is of vital imperative in social dynamics.

Table 5 explained and indicated that majority of the respondents $65.0 \%$ agreed that teacher's capacities building embody the same educational system, $75.9 \%$ were of the opinion that higher the skills on part of a teacher, more were yielding results, $74.8 \%$ agreed that consistent training were essential to achieve maximum results. Education is a base of dynamism, could only enshrines the student $\&$ teachers as it is characterized by frequent training in order to cope with prevalent with situation while foreseeing into the future. Disclosed that it is the training which empowers trainees command on the subjects and pedagogy. Awareness about the students' standard and responsibility of grooming young generation further accelerates the process. Solid academic background due to general education is a major factor in determining the professional and academic quality of a teacher. The learning of teaching methods and techniques in education and specialized areas further expedite the process. It is again the education which a teacher receives in schools and colleges enabling him to earn prestige, status while accumulating with the longstanding commitment of a teacher. A teacher needs to get training while opting for teaching as profession as an essential part of his proficiency and advancement in career. 
Table 5. Perception of sampled respondents about teacher capacity building.

\begin{tabular}{|l|l|l|l|l|}
\hline Sr. no. & Statements & Yes & No & Uncertain \\
\hline 1. & Teacher capacity building embody in same educational system & $351(65.0)$ & $147(27.2)$ & $42(7.8)$ \\
\hline 2. & Higher the skills on part of teacher more is yielding results & $410(75.9)$ & $100(18.5)$ & $30(5.6)$ \\
\hline 3. & Consistent training is essential to achieve maximum results & $404(74.8)$ & $66(12.2)$ & $70(13.0)$ \\
\hline 4. & 2013 policy reforms ensure capacity building phenomena & $384(71.1)$ & $130(24.1)$ & $26(4.8)$ \\
\hline 5. & $\begin{array}{l}\text { New policy reforms equip you to counter the latest demand in } \\
\text { your profession }\end{array}$ & $370(68.5)$ & $138(25.6)$ & $32(5.9)$ \\
\hline 6. & $\begin{array}{l}\text { Training has been imparted to the teachers after the } \\
\text { introduction of educational reforms }\end{array}$ & $433(80.2)$ & $68(12.6)$ & $39(7.2)$ \\
\hline 7. & $\begin{array}{l}\text { Many of the teachers are still not competent enough to teach } \\
\text { under the new system }\end{array}$ & $434(80.4)$ & $75(13.9)$ & $31(5.7)$ \\
\hline 8. & $\begin{array}{l}\text { The training has enhanced the commitment of the teachers } \\
\text { towards their profession }\end{array}$ & $448(83.0)$ & $77(14.3)$ & $15(2.8)$ \\
\hline 9. & $\begin{array}{l}\text { The training has directly affected the students performance in } \\
\text { a positive direction }\end{array}$ & $454(84.1)$ & $55(10.2)$ & $31(5.7)$ \\
\hline
\end{tabular}

Similarly, $71.1 \%$ agreed that 2013 policy reforms ensured capacity building phenomena; $68.5 \%$ agreed that new policy reforms equip teachers to counter the latest demand in their profession; $80.2 \%$ accepted that training has been imparted to the teachers after the introduction of educational reforms, $80.4 \%$ respondents were of the opinion that many of the teachers were still not competent enough to teach under the new system. It is indicated from these findings that education as sector of human development, though had the prevalence, but ineffective in deliverance. It was marred by the indication of teachers devoid of any merit considerations. These were in line with the finding of Amin $\underline{16}$ who reported that the KP government after 2013 introduced major reforms in the education sector. Recruitment to an educational institution was first carried out through the NTS to end political interference and appoint qualified people. Apart from this, the government focused on teacher's training to strengthen their ability to meet all professional requirements which has been emphasis of the government policies since independence of the country in 1947. Currently, there are more than 300 teacher training institutes offering a number of initial teacher education (ITE) programs in Pakistan in the public and private sectors. Like Pakistan, teacher's capacity is considered vital in educational development throughout the world. In fact, a solid and effective education system of a country cannot be built without the capacity building of the teachers and following of a continuous assessment of teaching activities at schools. For that, the government policies and program to provide the necessities measures and resources needed to build the teacher; capacities according to the needs of the 21 st century.

Moreover, $83.0 \%$ respondents disclosed that the training has enhanced the commitment of the teachers towards their profession; $84.1 \%$ were of the opinion that the training has directly affected students' performance in a positive direction. Provision of training to teachers has been proved as catalyst in exploring the potentials and their subsequent application through the transmission process to the students. It is also supported the fore mentioned findings that training an important investment for the improvement of quality education. A qualitative change in education is the need of the day not only for enhancing teachers' capability, but also for dynamic feature of development of countries growth required for a countries growth. Further added that there is a positive relationship between quality teaching and teacher's qualification albeit, proper attitude, practice and evaluation through capacity building is imperative to accelerate the process on sustainable grounds. Initial trainings play an important role towards the professional development of teachers. It is assumed that 21 st century education needs competent teacher to meet the changing environment in the class. The quality education and improvement in students' performance can only be achieved through a quality 
change, prevailing around a teacher. Educational reforms cannot be implemented without equipping teachers with the necessary capability, skills and temperament. ${ }^{17}$ It is concluded that a transitional stage was indicated by the above mentioned findings.

However, a ray of hope of growth \& development was emanated as teachers and other relevant stakeholders reposed confidence in the reforms indicated, chosen, and implemented by the 2013 policy.

\subsection{Bi-variate Analysis}

\subsubsection{Association Between Teacher Capacity Building and Improvement in Primary Education}

Capacity building is a main approach revolving around empowering persons in terms of skills \& knowledge. Its main aim is furthering the initiatives in order to cater to the existing needs \& requirements at institutional level and also has the vision to chalk out further strategies. Teachers' capacity building has been the other major priority of the government policies since the independence of the country in 1947. However, a dynamic shift in the policy was introduced in the form of the 18th amendment shifting some responsibilities to the provinces. Each province, then capitalized on the constitutional power by reinvigorating and revamping a number of human development initiatives. Education was a prime target of the KP government with major emphasis on primary level in order to mitigate the early drop out by focusing on teachers' capacity with a number of activities like regular arrangement of trainings, getting higher education and making them punctual through initiative of new administrative measures, etc. To ascertain the teachers' capacity building in relationship to improving primary level education, an association between primary education and capacity building is measured and shown in Table 6.

The results showed a highly significant $(P=0.000)$ association between improvement in primary education and consistent compulsory training to achieve maximum results. Similarly, a significant association $(P=0.035)$ showed that new policy reforms equip teachers to counter the latest demand in their profession and improvement in primary education. It is evident that the provision of training for teachers is a significant turn in the development initiatives. Any policy, entailed with consistent pace of training not only helps the trainee to acquire the latest know-how, but also these learned personals then work as catalyst in dissemination of new knowledge. These findings were in alignment to who supported the aforementioned findings that training is a very important investment for the improvement of quality education. A qualitative change in education is the need

Table 6. Association between teacher capacity building and improvement in primary education

\begin{tabular}{|l|l|l|}
\hline Independent variables & Dependent variables & Statistics \\
\hline Teacher capacity building & & \\
\hline Teacher capacity building embody in same educational system & Improvement in primary education & $\boldsymbol{\chi}^{2}=6.824(0.145)$ \\
\hline Higher the skills on part of teacher more is yielding results & Improvement in primary education & $\boldsymbol{\chi}^{2}=2.095(0.718)$ \\
\hline Consistent training is essential to achieve maximum results & Improvement in primary education & $\boldsymbol{\chi}^{2}=110.112(0.000)$ \\
\hline 2013 policy reforms ensure capacity building phenomena & Improvement in primary education & $\boldsymbol{\chi}^{2}=307.383(0.000)$ \\
\hline $\begin{array}{l}\text { New policy reforms equip you to counter the latest demand in } \\
\text { your profession }\end{array}$ & Improvement in primary education & $\boldsymbol{\chi}^{2}=10.354(0.035)$ \\
\hline $\begin{array}{l}\text { Training has been imparted to the teachers after the introduction } \\
\text { of educational reforms }\end{array}$ & Improvement in primary education & $\boldsymbol{\chi}^{2}=100.808(0.000)$ \\
\hline $\begin{array}{l}\text { Many of the teachers were still not competent enough to teach } \\
\text { under the new system }\end{array}$ & Improvement in primary education & $\boldsymbol{\chi}^{2}=23.737(0.000)$ \\
\hline $\begin{array}{l}\text { The training has enhanced the commitment of the teachers } \\
\text { towards their profession }\end{array}$ & Improvement in primary education & $\boldsymbol{\chi}^{2}=1.535(0.820)$ \\
\hline $\begin{array}{l}\text { The training has directly affected the students performance in a } \\
\text { positive direction }\end{array}$ & Improvement in primary education & $\boldsymbol{\chi}^{2}=2.896(0.575)$ \\
\hline
\end{tabular}

Source: Survey-2018 
of the day not only for enhancing teachers' capability, but also due to its dynamic feature of development is required for a country growth. These findings vividly depict the importance of consistent training compulsory for good results of students because through consisting training, teachers update their teaching skills. Investing more in teachers' trainings where investment in human capital positively influences students' performance. These efforts on the one hand enables the teacher to attain knowledge, skills and experience they need while on the other hand, they can share with other fellow teachers to achieve the quality education at school level and a more holistic manner. $\underline{18}$

The study further explained that a highly significant association $(P=0.000)$ was found between improvements in primary education and many of the teachers still not competent enough to teach under the new system. 19 These findings could be attributed to unskilled teachers' appointment made earlier either on a political basis or not meeting the minimum merit criteria. Such appointments usually do not anticipate getting the burden of learning, rather targeting to keep the status quo. These teachers were not capable to go with the same pace with the new system because new technologies were introduced by the government after 2013 with the slogan of change in KP. $\underline{20}$ It revealed that teacher is the backbone of an education system and that a qualified teacher plays an important role in the education system. However, as far as Pakistan is concerned, most of the teachers are so old incapacitated that they do not have the ability to cope with the changing dynamics based on innovation and improvement.

Likewise, a highly significant association $(P=0.000)$ explained that 2013 policy reforms ensured capacity building phenomena and improvement in primary education. Similarly, a highly significant association $(P$ $=0.000$ ) showed that training has been imparted to the teachers after the introduction of educational reforms. 1 1 These trainings imparted to teachers under the umbrella of 2013 reforms envisage a step wise capacity building of teachers as indicated by the results. It is indicative of the fact that the new government in KP after 2013, made policy reforms and ensured teachers' capacity building through giving different teachings skills and techniques. It is primarily aimed at strengthening the skills being imparted to teachers to comply with the professional needs. Such aims have been the cornerstone of each policy, particularly about education by the state of Pakistan since its independence. Such initiatives not only bring about the desired changes, but also putt the nation on the path of progress. It also serves to bring consistency in the policies of revisiting through the process of monitoring and evaluation. The present policy shift by the KP government unshattered stands of KP to innovate the educational trends by taking along all the stakeholders in order to achieve maximum.

However, contrary to the above, a non-significant $(P=$ 0.820 ) association existedbetweenimprovementin primary education and enhancement in teachers' commitment towards their profession. It could be deduced from these findings that although the government has introduced reforms, hoverer teachers' commitments to comply with the reforms are not fully materialized. Further added that there is a positive relationship between quality teaching and teachers' qualification albeit, proper attitude, practice and evaluation through capacity building is imperative to accelerate the process on sustainable grounds. Initial trainings play an important role as a huge loop towards the professional development of teachers. It is assumed that 21 st century education needs competent teacher to meet the changing environment in the class.

In addition, a non-significant $(P=0.718)$ association showed between higher the skills on part of teachers' the more is yielding of results and improvement in primary education. In addition, a non-significant $(P=0.145)$ association existed between improvement in primary education and teachers' capacity building in the same educational system. Similarly, a non-significant $(P=$ 0.575) association showed that training has directly affected the students' performance in a positive direction. These results are further endorsing the earlier results that teachers were not more prone to getting themselves changed as per policy requirements. Apathy on part of teachers could be attributed to their relative age, noncompetence and lacking of professional vision in order to capitulate on the situational needs. It also disclosed that it is the training which empowers trainees' command over the subjects and pedagogy. Awareness about the students' standard and responsibility of grooming young generation further accelerates the process. Solid academic background due to general education is a major factor in determining the professional and academic quality of a teacher. The learning of teaching methods and techniques in education and specialized areas further expedite the process. It is again the education which a teacher receives in school and college enabling him to earn prestige, status while accumulating with the longstanding commitment 
of a teacher. A teacher needs to get training while opting for adopting teaching as profession as an essential part of his proficiency and advancement in career. It also explored that the main objective of the training is to improve the quality of teachers in order to make them more effective in their profession.

\subsection{Multivariate Analysis}

\subsubsection{Association Between Teacher Capacity Building and Improvement in Primary Education Controlling Age}

In Table 7, the influence of the age grade on the association of teacher capacity building and improvement in primary education showed that the association of teacher capacity building and improvement in primary education was significant $(P=0.004)$ for the respondents with age groups $20-35$ years. However, the relationship of the above mentioned variables was non-significant $(P$ $=0.643)$ for the age groups between 36 and 45 years. In addition, a significant association $(P=0.020)$ between these variables was established from the above age groups representing 46-60 years. Based on the above associations, the relationship among all the age groups of teacher capacity building and improvement in primary education was non-spurious for the age group 20-35 and 46-20 years, while a spurious relation was discovered for the age groups between 36 and 45 years. These findings vividly depict the importance of consistent training is compulsory for good results of students because through

Table 7. Showing association between teacher capacity building and improvement in primary education controlling age

\begin{tabular}{|l|l|l|l|}
\hline $\begin{array}{l}\text { Age } \\
\text { groups }\end{array}$ & $\begin{array}{l}\text { Independent } \\
\text { variables }\end{array}$ & $\begin{array}{l}\text { Dependent } \\
\text { variable }\end{array}$ & $\begin{array}{l}\text { Statistics } \\
\text { chi-square } \\
(\boldsymbol{P} \text {-value })\end{array}$ \\
\hline $\begin{array}{l}\text { 20-35 } \\
\text { years }\end{array}$ & $\begin{array}{l}\text { Teacher capacity } \\
\text { building }\end{array}$ & $\begin{array}{l}\text { Improvement } \\
\text { in primary } \\
\text { education }\end{array}$ & $\begin{array}{l}\boldsymbol{\chi}^{2} 7.059 \\
P=0.004\end{array}$ \\
\hline $36-45$ & $\begin{array}{l}\text { Teacher capacity } \\
\text { building }\end{array}$ & $\begin{array}{l}\text { Improvement } \\
\text { in primary } \\
\text { education }\end{array}$ & $\begin{array}{l}\chi^{2} .003 \\
P=0.643\end{array}$ \\
\hline $46-60$ & $\begin{array}{l}\text { Teacher capacity } \\
\text { building }\end{array}$ & $\begin{array}{l}\text { Improvement } \\
\text { in primary } \\
\text { education }\end{array}$ & $\begin{array}{l}\chi^{2} 7.212 \\
P=0.020\end{array}$ \\
\hline
\end{tabular}

consisting training the teachers become agile to equip themselves, with latest skills of dissemination.

Investing in teacher training corresponds to trained human capital, which could yield more promising results. It also explored that the main objective of the training is to improve the quality of the teacher in order to make these more versatile in their profession. $\underline{22}$

\subsubsection{Association Between Teacher Capacity Building and Improvement in Primary Education Controlling Educational Qualification}

While controlling the influence of the educational qualification and ascertaining the teacher capacity building and improvement in a primary education relationship, the respondents with the educational qualification with master degree was found significant $(P$ $=0.025)$ and non-spurious. Furthermore, the association for the educational qualification with BE.d was found non-significant $(P=0.249)$ but spurious. Similarly, the educational qualification PTC was found non-significant $(P=0.060)$ and spurious as well. By comparing these with level of significance at bivariate level. $\underline{23}$ These findings were in consonance to the preceding results shown in Table 8. It was concluded that irrelevant and non-specific qualification of the teacher had profound effects with greater variations to the nature of qualification possessed by the teacher. Explored that solid academic background due to general education is a major factor in determining the professional and academic quality of the teacher. Who reported that the KP government after 2013 introduced

Table 8. Showing association between teacher capacity building and improvement in primary education controlling educational qualification

\begin{tabular}{|l|l|l|l|}
\hline $\begin{array}{l}\text { Educational } \\
\text { qualification }\end{array}$ & $\begin{array}{l}\text { Independent } \\
\text { variables }\end{array}$ & $\begin{array}{l}\text { Dependent } \\
\text { variable }\end{array}$ & $\begin{array}{l}\text { Statistics } \\
\text { chi-square } \\
(\boldsymbol{P} \text {-value })\end{array}$ \\
\hline Master & $\begin{array}{l}\text { Teacher } \\
\text { capacity } \\
\text { building }\end{array}$ & $\begin{array}{l}\text { Improvement } \\
\text { in primary } \\
\text { education }\end{array}$ & $\begin{array}{l}\boldsymbol{\chi}^{2} 6.103 \\
P=0.025\end{array}$ \\
\hline BE.d & $\begin{array}{l}\text { Teacher } \\
\text { capacity } \\
\text { building }\end{array}$ & $\begin{array}{l}\text { Improvement } \\
\text { in primary } \\
\text { education }\end{array}$ & $\begin{array}{l}\boldsymbol{\chi}^{2} 39.339 \\
P=0.249\end{array}$ \\
\hline PTC & $\begin{array}{l}\text { Teacher } \\
\text { capacity } \\
\text { building }\end{array}$ & $\begin{array}{l}\text { Improvement } \\
\text { in primary } \\
\text { education }\end{array}$ & $\begin{array}{l}\boldsymbol{\chi}^{2} 10.496 \\
P=0.060\end{array}$ \\
\hline
\end{tabular}


Table 9. Showing association between teacher capacity building and improvement in primary education controlling teaching experience

\begin{tabular}{|l|l|l|l|}
\hline $\begin{array}{l}\text { Teaching } \\
\text { experience }\end{array}$ & $\begin{array}{l}\text { Independent } \\
\text { variables }\end{array}$ & $\begin{array}{l}\text { Dependent } \\
\text { variable }\end{array}$ & $\begin{array}{l}\text { Statistics } \\
\text { chi-square } \\
(\boldsymbol{P} \text {-value })\end{array}$ \\
\hline $1-10$ years & $\begin{array}{l}\text { Teacher } \\
\text { capacity } \\
\text { building }\end{array}$ & $\begin{array}{l}\text { Improvement } \\
\text { in primary } \\
\text { education }\end{array}$ & $\begin{array}{l}\boldsymbol{\chi}^{2} 13.650 \\
P=0.000\end{array}$ \\
\hline $11-20$ & $\begin{array}{l}\text { Teacher } \\
\text { capacity } \\
\text { building }\end{array}$ & $\begin{array}{l}\text { Improvement } \\
\text { in primary } \\
\text { education }\end{array}$ & $\begin{array}{l}\boldsymbol{\chi}^{2} 1.571 \\
P=0.196\end{array}$ \\
\hline $21-30$ & $\begin{array}{l}\text { Teacher } \\
\text { capacity } \\
\text { building }\end{array}$ & $\begin{array}{l}\text { Improvement } \\
\text { in primary } \\
\text { education }\end{array}$ & $\begin{array}{l}\boldsymbol{X}^{2} 37.758 \\
P=0.001\end{array}$ \\
\hline
\end{tabular}

major reforms in the education sector, as recruitment to an educational institution was first carried out through the NTS to end political interference and appoint qualified people.

\subsubsection{Association Between Teacher Capacity Building and Improvement in Primary Education Controlling Teaching Experience}

The influence of the teaching experience on the association of teacher capacity building and improvement in primary education (Table 9) disclosed that the association of teacher capacity building and improvement in primary education was highly significant $(P=0.000)$ for the respondents with the teaching experience 1-10 years. Furthermore, the association of the above mentioned variables was non-significant $(P=0.196)$ between 11 and 20 years' experience. $\underline{24}, \underline{25}$ In addition to this, a significant association $(P=0.001)$ was found for the teaching experience $21-30$ years, respectively. $\frac{26}{}$ Based on these similarities, the significance level of the teaching experience on the respondents perception of the teacher capacity building and improvement in primary education was found non-spurious as in the above mentioned teaching experience $1-10$ and 21-30 years and spurious for the teaching experience 11-20 years. Experienced teachers have a greater influence on student performance in elementary and secondary schools. Because experienced teachers have a lot of basic knowledge and on the basis of their experience, he knows how to motivate, to teach, and to socialize students at this early stage.
Such teachers are more knowledgeable about classroom management skills and can cope with different situations as he becomes master and uses his expertise to make students the nation's future. ${ }^{27}$ In addition, the experienced teacher is expected to impart relevant knowledge and be more able to concentrate effectively. $\underline{28}, \underline{29}$

\section{Conclusions}

The study explored that teacher capacity building enabled the teachers to positively trickle down the state of the art knowledge to students in a moral way. The introduction of reforms indicated a surge in the capacity building of teachers through various training \& reforms courses being ensured in policy reform as a positive in vogue. The study further explored that being in transitions that policy reforms had yet to reach its maximum achievements and still some of the teachers were laggards and had laser intention to improve their professional lot. The study further divulged that teachers with young age and at the twilight of professional life had taken maximum benefits by reforming themselves; teachers with higher qualification had more inclination to enhance their capacity in comparison to teachers with low level of education. Consistent and sustained efforts by reinvigorating the policy of teacher capacity building and the replication of this model to other part of the country with particular and to the developing countries in general were put forwarded as policy implications in light of this study.

\section{References}

1. Educational planning: a turning point in education and development in Nigeria. [cited 2001]. https://books. google.co.in/books/about/Educational_Planning. html?id=U3bsAAAAMAAJ\&redir_esc $=y$.

2. Ajayi K. Effective planning strategies for UBE programmes. In UBE forum. J Basic Educ Nigeria. 2001;1(1):23-33.

3. Onyeagba J. Objectives of vocational education at primary, secondary and tertiary levels. Educ outcome. 2006:36-46.

4. Primary school education reforms for better foundation of education in Nigeria. [cited 2013 May]. https://www. researchgate.net/publication/314544038_Primary_ Education_as_a_Foundation_for_Qualitative_Higher_ Education_in_Nigeria. 
5. Sen A. Primary schooling in West Bengal. Prospects Q Rev Comp Educ. 2010;155(3):311-20.

6. Curriculum framework for quality teacher education. [cited 1998]. http://anmaheshwari.net/ncte.htm.

7. Shami PA, Hussain KS. Development of education in Pakistan. Academy of Educational Planning and Management; 2005. P. 6.

8. Rao RR, Rao BD. Methods of teacher training. Discovery Publishing House; 2005. P. 1-2.

9. Hiebert J, Morris AK, Berk D, Jansen A. Preparing teachers to learn from teaching. J Teach Educ. 2007;58(1):47-61.

10. National education policy. [cited 2009]. http://itacec.org/ document/2015/7/National_Education_Policy_2009.pdf.

11. Teacher capacity building in teaching and learning: the changing role of school leadership. [cited 2010 Jan]. https:// www.researchgate.net/publication/260210236_Teacher_ capacity_building_in_teaching_and_learning_The_ changing_role_of_school_leadership.

12. Duze CO. Administrative constraints affecting curriculum development and implementation in Nigeria: towards education for sustainable development. J Sociol Educ Afr. 2009;8(1):185-98.

13. Global perspectives on teacher learning: improving policy and practice. [cited 2007]. https://unesdoc.unesco.org/ ark:/48223/pf0000150261.

14. The new meaning of educational change. [cited 1991]. https://michaelfullan.ca/books/new-meaning-educationalchange/.

15. Social science statistics, its elements and applications. [cited 1978]. https://www.abebooks.com/products/isbn/9780876 208601/10735086119\&cm_sp=snippet-_-srp4-_-PLP24.

16. Amin T. Education, law enforcement PTI-led KP government's reforms bringing positive changes. Business Recorder; 2016. P. 1-2.

17. Quality assurance of teacher education in Africa. [cited 2013]. http://www.iicba.unesco.org/sites/default/files/ Fundamentals \%20 of\%20 Teacher $\% 20$ Education $\% 20$ Development\%20No5.pdf.

18. Darling-Hammond L, Wise AE, Pease SR. Teacher evaluation in the organizational context: a review of the literature. Rev Educ Res. 1983;53(3):285-328.
19. Ashraf I, Ashraf F, Saeed I, Gulzar H, Shah K, Azhar N, et al. Reasons for low performance of teachers: a study of government schools operating in Bahawalpur City, Pakistan. Int J Acad Res Prog Educ Dev. 2015;4(2):105-17.

20. Miller JF, Freiberg C, Rolland MB, Reeves MA. Implementing computerized language sample analysis in the public school. Top Lang Disord. 1992;12(2):69-82.

21. Shahzad S, Ghazi SR, Ali R, Shah S.F. Quality of primary education in Khyber Pakhtunkhwa Pakistan. Int J Phys Soc Sci. 2013;3(9):261-74.

22. Abu-Ghaida D, Klasen S. The costs of missing the millennium development goal on gender equity. World Dev. 2004;32(7):1075-107.

23. Ali S. The small and medium enterprises and poverty in Pakistan: an empirical analysis. Eur J Bus Econ. 2013;8(2):25-30.

24. Fatima J, Naseer Ud Din M. Evaluative study of MA education programmes of teacher education at higher education level in Pakistan. Contemp Iss Educ Res. 2010;3(12):29-34.

25. Hervie DM, Winful EC. Enhancing teachers' performance through training and development in Ghana education service (a case study of Ebenezer senior high school). J Hum Resour Manag. 2018;6(1):1-8.

26. Ahmed M. Factors affecting initial teacher education in Pakistan: historical analysis of policy network. International J Hum Soc Sci. 2012;13(2):104-13.

27. Gibbons S, Kimmel H, O'Shea M. Changing teacher behavior through staff development: implementing the teaching and content standards in science. Sch Sci Math. 1997;97(6):302-10.

28. Stringfield S, Teddlie C. School, classroom, and student level indicators of rural school effectiveness. J Res Rural Educ. 1991;7(3):15-28.

29. Bhola HS. A look before and after the Delors commission report: Jomtien, Hamburg \& Dakar as markers of adult education. Convergence. 2000;33(3):84. 